\title{
AGRICULTURE, LIVESTOCK and FISHERIES
}

An Open Access Peer Reviewed Journal

Open Access

Res. Agric. Livest. Fish.

Research Article

Vol. 5, No. 2, August 2018 : 279-291.

\section{ACCELERATING NATURAL BREEDING OF CUCHIA AND CREATING EMPLOYMENT OPPORTUNITIES OF POOR PEOPLE THROUGH HOUSEHOLD BASED CUCHIA FARMING}

\begin{abstract}
A M Farhaduzzaman ${ }^{1 \star}$, Md. Abdullah A I Mahamud ${ }^{2}$, Shipon Das $^{3}$ and Kamruzzaman ${ }^{4}$
'Deputy Manager (Program), Palli Karma Sahayak Foundation (PKSF), Sher-e-Bangla Nagar, Dhaka-1207, Bangladesh, ${ }^{2}$ Manager, Agriculture, Fisheries and Livestock Department, HEED Bangladesh, Dhaka, Bangladesh; ${ }^{3}$ Department of Fisheries, University of Rajshahi, Rajshahi6205; ${ }^{4}$ Department of Fisheries Technology, Faculty of Fisheries, Bangladesh Agricultural University, Mymensingh-2202, Bangladesh.
\end{abstract}

*Corresponding author: A M Farhaduzzaman; E-mail: farhadpksf@gmail.com

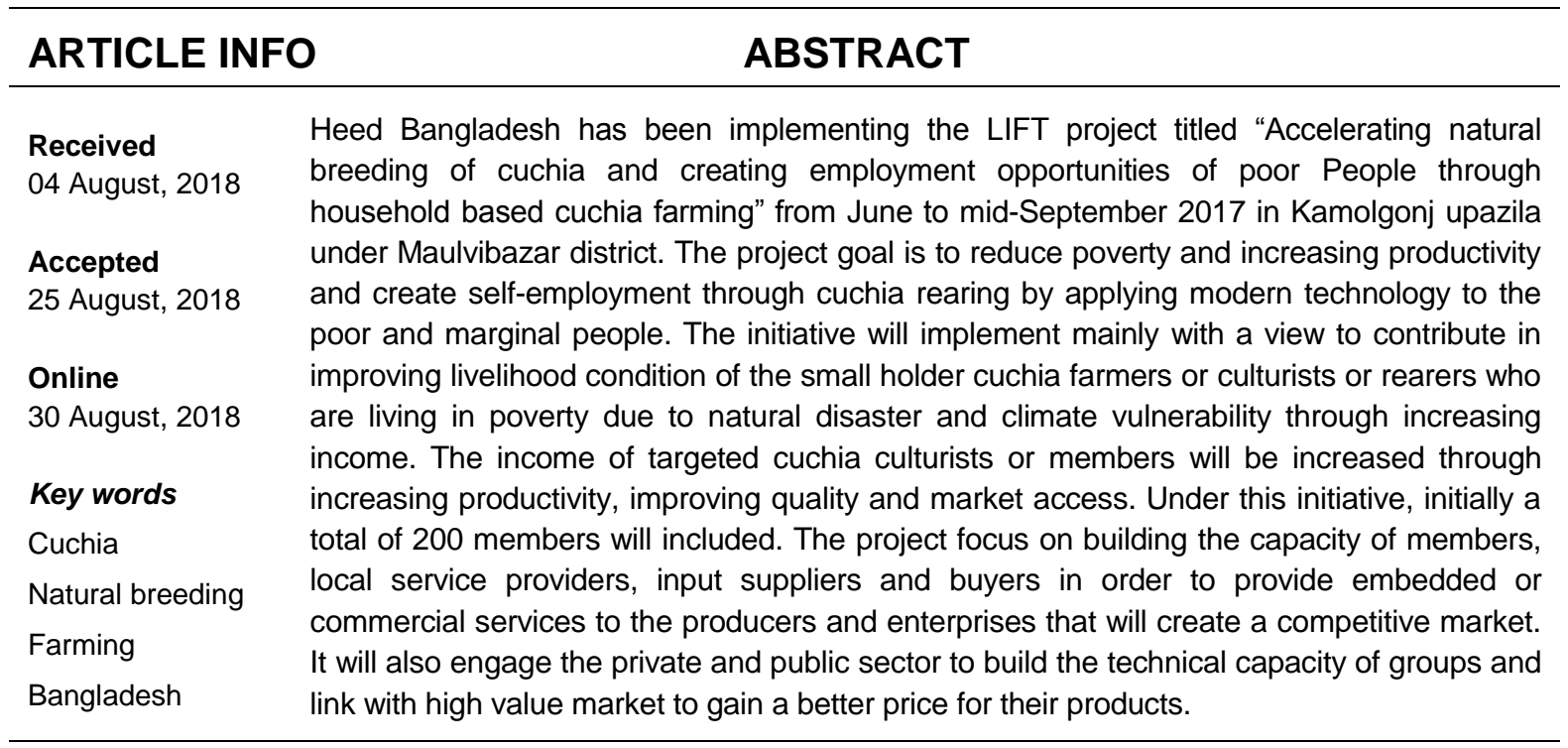

To cite this article: Farhaduzzaman A M, M Abdullah A I Mahamud, S Das and Kamruzzaman, 2018. Accelerating natural breeding of cuchia and creating employment opportunities of poor people through household based cuchia farming. Res. Agric. Livest. Fish. 5 (2): 279-291.

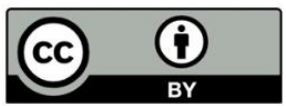

This is an open access article licensed under the terms of the

Creative Commons Attribution 4.0 International License

www.agroaid-bd.org/ralf, E-mail: editor.ralf@gmail.com 


\section{INTRODUCTION}

The Gangetic mud eel, Monopterus cuchia (Figure 1) is The Gangetic mud eel, Monopterus cuchia is a freshwater air breathing, swamp mud eel is locally known as cuchia. It occurs in the freshwater of Bangladesh, Pakistan, Northern and Northeastern India and Nepal (Talwar and Jingran, 1991). Once, indigenous M. cuchia was abundant throughout the Bangladesh, plenty in mud holes in shallow "beels" and 'boro' paddy fields particularly in Sylhet, Mymensingh and Tangail Districts (Rahman, 1989). But presently this fish is hardly found in the open water bodies. The IUCN, Bangladesh (2000) enlisted M. cuchia as vulnerable species in the country. Improper water management policy for irrigation, over exploitation and various ecological changes in natural habitat; this species is threatened now (Diaster, 1990; Chakraborty and Nur, 2009). Considering the importance of this species in nutritional, economic and biodiversity point of view, the conservation and propagation are needed. Studies on the reproductive biology of the fish are essential for evaluating the conservation potentialities of its stock, life history, cultural practice and actual management of the fish (Lagler 1956; Doha and Hye 1970).

Heed Bangladesh has been implementing the LIFT project titled "Accelerating natural breeding of cuchia and creating employment opportunities of poor People through household based cuchia farming" from June to mid September 2017 in Kamolgonj upazila under Maulvibazar district. The project goal is to reduce poverty and increasing productivity and create self-employment through cuchia rearing by applying modern technology to the poor and marginal people. The initiative will implement mainly with a view to contribute in improving livelihood condition of the small holder cuchia farmers or culturists or rearers who are living in poverty due to natural disaster and climate vulnerability through increasing income. The income of targeted cuchia culturists or members will be increased through increasing productivity, improving quality and market access. Under this initiative, initially a total of 200 members will included. The project focus on building the capacity of members, local service providers, input suppliers and buyers in order to provide embedded or commercial services to the producers and enterprises that will create a competitive market. It will also engage the private and public sector to build the technical capacity of groups and link with high value market to gain a better price for their products.

The prime aim of this study is to assess the life and livelihood condition of cuchia farmers in the aforesaid areas. The basic objectives of this baseline survey are to assuming the benchmark of cuchia farmers in the study area, which includes demographic, income, occupations, existing GO \& NGO services and market linkage activities as well as its status etc. Provide tentative suggestions to achieve the sustainable livelihood and employment creation through cuchia farming in the working area. Utilizing the baseline data with the evaluation data to compare the progress of project.

\section{About Monopterus cuchia}

Monopterus cuchia, commonly known as Gangetic mud eel, cuchia. In Bangladesh locally it is known as Kuchia, cuchia, kucha, Maitta cuchia, kunche etc (Figure 1).

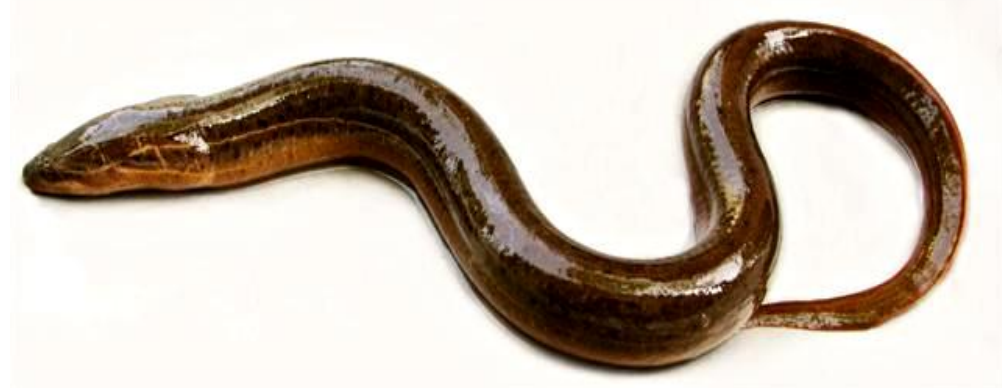

Figure 1. Monopterus cuchia

\section{Distributions of Cuchia}

Asia: Pakistan, India (Northern \& Northwestern areas), Nepal, Bangladesh and Myanmar ((Talwar and jhingran, 1991). 


\section{METHODOLOGY}

\section{Study area and Period}

This survey has been conducted for fulfilment of the contract between Heed Bangladesh and Four Face Communication (FFC) for conducting baseline survey of "Accelerating natural breeding of cuchia and creating employment opportunities of poor People through household based cuchia farming" in Komolgonj upazilla of Maulvibazar district (Figure 2). Based on the pre-test, marginal adjustments in the questionnaires were made and consequently study had been conducted from June to mid of September 2017.

\section{Qualitative Information Collection}

Qualitative information was collected mainly through Focus Group Discussion (FGD), Key informant interviews (KII). The FGDs and KII conducted by the survey team.

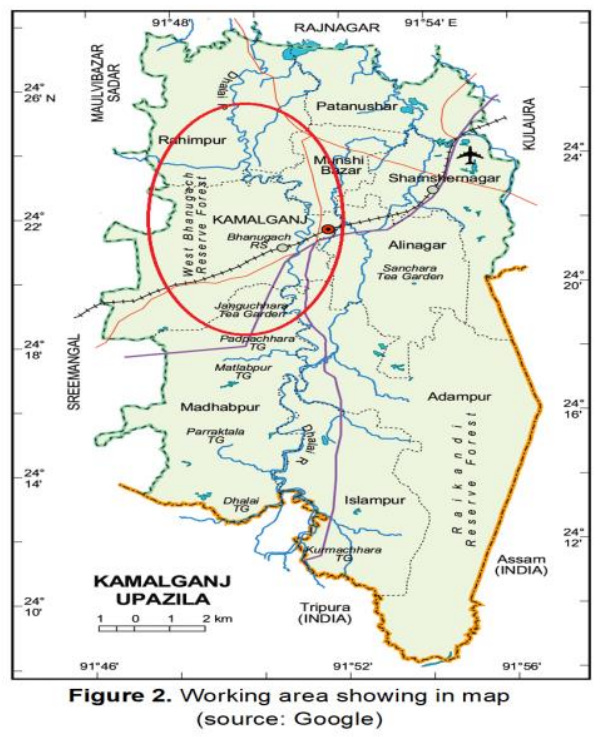

\section{Analyze the collected data}

The study team started to input the data as per output tables prepared by the Team. After intensive processing, synthesizing and analysis of data in the light of the scope of the study report writing was started. SPSS was utilized for processing the information collected.

\section{Limitations of the Study}

At the time of baseline data collection, some group member were not covered by Field Enumerators due to valid reasons including absent of household members (door lock), migration and disallow to give interview etc. It is presumed that the income and expenditure data is usually not very accurate, given the problems of poor recall by the respondents. There was tendency to under-report income for the fear of exclusion from a development programme and difficulties of estimating income from unpaid work.

\section{RESULTS}

\section{Demographic Condition of the Respondents}

Demographic condition is often measured by education, income, gender and occupation to conceptualize the social status or class of an individual or group. During survey, respondents in Kamlgonj upazilla mostly found as hindu and monipure and few are muslims. Financial condition of the surveyed people are not good enough, they have limited opportunities to get education, others employment and place of family status to contribute for self, family and society. Present section investigated the demographic factors to understand the background and present condition of the respondents in the survey area.

\section{Status of Respondents as per Religion}

Above table showed that Kamalgonj upazilas are mixed with Hindu, Manipuri ethnic community and Muslims. Among the respondent only 16\% (31) are Muslim and 58\% (117) are Hindu and 26\% (52) are Monipure. According to the survey it can be mentioned that cuchia culture and farming is very famous and popular to the hindu and monipure community rather than muslim community.

\section{Educational Qualifications}

According to the survey it was found that Out of 200 respondents $7 \% \mathrm{HH}$ Heads were illiterate. About $30 \%$ $\mathrm{HH}$ head passed the primary level education and $11 \% \mathrm{HH}$ heads passed SSC. Among the respondents $5.5 \%$ household heads were found who passed HSC and $10.5 \%$ found as graduate. 
Table 1. Household Size of the Respondents

\begin{tabular}{|lllll|}
\hline SL No. & Members in each HH & Number of $\mathbf{H H}$ & Total members & Average HH size \\
\hline 1 & 2 & 4 & 8 \\
2 & 3 & 32 & 96 \\
3 & 4 & 84 & 336 \\
4 & 5 & 53 & 265 & \\
5 & 6 & 19 & 114 \\
6 & 7 & 7 & 49 \\
7 & 9 & 1 & 9 \\
& Total & $\mathbf{2 0 0}$ & $\mathbf{8 7 7}$ \\
\hline
\end{tabular}

Above table showed the household size of the respondents. Among the respondents only $1 \mathrm{HH}$ have 9 members while $19 \mathrm{HHs}$ have 6,53 have 5 and 84 have 4 members in their household. Average household size found 4.38 which were similar to the national household survey.

\section{Primary Occupation of the Household Head}

According to the survey it was observed that among the respondent about $25 \%$ were farmer and $9 \%$ are involve with agriculture activities. Among other respondents $18 \%$ were small businessmen who actually called feriwala and $19 \%$ were day labour. This indicates that the people selected for cuchia culture were mostly poor. Only $3 \%$ people were involved with fish culture and fish trading. Actually, nobody culture cuchia for commercial purpose in the aforementioned upazila. LIFT project should give intensive attention to promote cuciha culture to the survey area.

\section{Sex Ratio of Respondent Household Members}

It was evident in the survey that 200 household consist of 877 people. Out of that number, $51 \%(451)$ are male and $49 \%$ (426) female found in the survey.

\section{Age Distribution of Household Members}

Irrespective of sex, the respondents household members having youth age group of 36 to 50 years were recorded highest (32\%) followed by $25 \%$ belongs to $5-19$ years, $22 \%$ belongs to $20-35$ years, $12 \%$ belongs to $51-65$ years, $4 \%$ having under 5 years and $5 \%$ belongs to older age group of more than 65 years. Thus, it has been envisaged that respondents $\mathrm{HH}$ constitutes higher number of youth and mid age group. This has given an opportunity to this project that this potential youth group can be used as catalyst for change the livelihoods of the households.

\section{Land, Pond and Income-Expenditure Related Information}

According to survey showed that $99 \% \mathrm{HHs}$ has their own homestead and only $1 \% \mathrm{HH}$ do not have their own land to build their house. People in the Kamalgonj upazilla are mostly poor. Due to hilly area, they are always affected by natural calamities like hilly flash flood, cold wave, access rainfall etc. Fish culture and fish related activities are not major occupation in the surveyed area. Survey showed that 53 respondent $(26.5 \%)$ don't have any pond of their own. A total of 127 respondents (63.5\%) have 1 pond, and only $1 \mathrm{HH}$ have 3,1 $\mathrm{HH}$ have 4 and $1 \mathrm{HH}$ have 5 ponds. But they don't culture cuchia in their pond. Average number of pond per respondent is 0.81 (Table 2 ). 
Table 2. Number of Pond in different household

\begin{tabular}{|lllll|}
\hline SL No. & Pond in each HH & Number of HH & Total pond & Average number of pond \\
\hline 1 & 0 & 53 & 0 & \\
2 & 1 & 127 & 127 & \\
3 & 2 & 17 & 24 & 0.81 \\
4 & 3 & 1 & 3 & \\
5 & 4 & 1 & 4 & \\
6 & 5 & 1 & 5 & \\
& Total & 200 & 163 & \\
\hline
\end{tabular}

According to the survey the following figure-3 showed that $25.5 \%$ respondent don't have any pond of their own. Among the respondent $51.5 \%$ have own single pond and $18 \%$ have joined owned \& leased pond and $5 \%$ have single leased pond among the served respondents pond details.

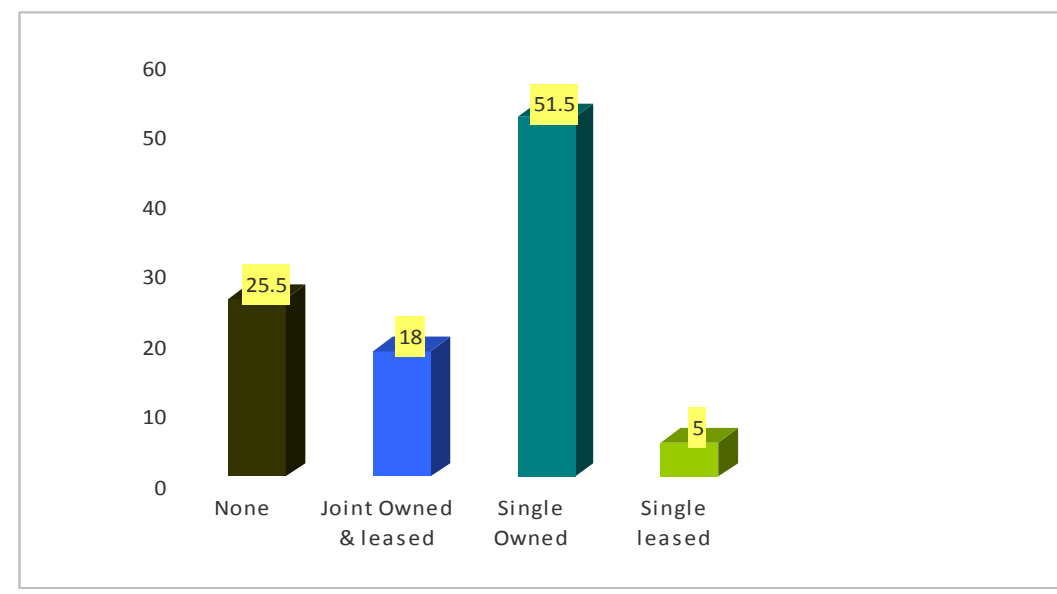

Figure 3. Status of Pond

\section{Earning Member in Respondent HHs}

Number of earning member is a crucial factor for poor HHs. Selected member under LIFT project in aforementioned upazilla is very poor and most of the $\mathrm{HHs}$ has one earning member and have no cultivable land though most of selected HHs main occupation is farmer. Family has more earning member become earn more has less chance to face poverty. This initiative has been taken to create alternate income source for poor $\mathrm{HHs}$ or create more earning member in a family. Below table showed that $110 \mathrm{HHs}(55 \%)$ have only 1 earning member and $73 \mathrm{HHs}(36.5 \%)$ have 2, and 11 (5.5\%) have 3 and only $3 \%$ have 4 earning member. Average number of earning member was found 1.56 .

\section{Primary Source of Income for Respondent HHs}

According to the survey findings among the respondents $33 \%$ are depends on agriculture, $15.5 \%$ run small business and $20 \%$ are day labour. Aquaculture is the minor source of income though there is sufficient number of pond found in the survey area. So cuchia culture can be the best option for livelihood of that community.

\section{Monthly Expenditure of Respondent HHs}

It was observed in the survey that $45 \% \mathrm{HHs}$ average monthly expenditure ranges from 10,001-15,000 taka and $24 \% \mathrm{HHs}$ expenditure ranges from $5001-10,000$ taka. On the other hand, only $4.5 \% \mathrm{HH}$ average monthly expenditure is less than 5,000 taka \& only $7.5 \% \mathrm{HHs}$ average monthly expenditure is more than 20,000 taka. Survey also showed that average monthly expenditure among 200 respondents found as 12,307 taka which was almost closer to average month income. 


\section{Aquaculture Experiences of the Respondents}

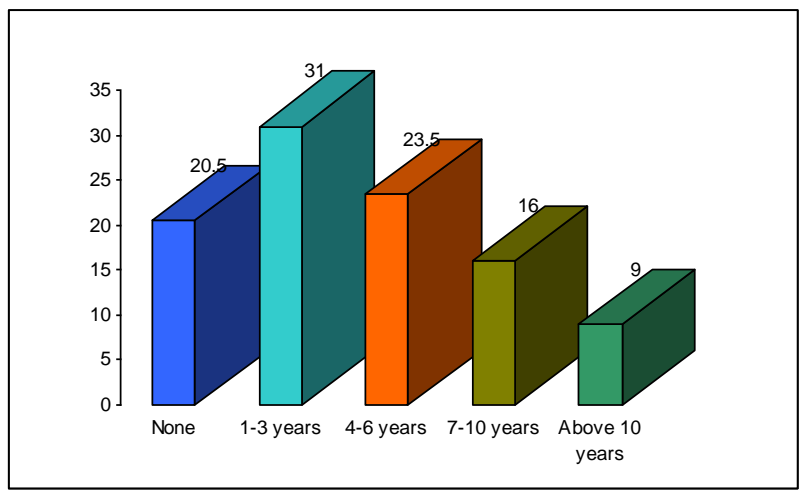

Figure 4. Age-basis experience of aquaculture

Above Figure 4 showed that $20.5 \% \mathrm{HHs}$ have no experience in aquaculture, $23.5 \% \mathrm{HHs}$ have $4-6$ years, $31 \% \mathrm{HHs}$ have $1-3$ years, $16 \% \mathrm{HHs}$ have $7-10$ years and $9 \% \mathrm{HHs}$ have over 10 years of aquaculture experiences. So, it is clear that people of surveyed areas have enough knowledge on aquaculture that directly helps to implement LIFT initiative.

\section{Loan and Savings Information}

\section{Whether Respondent HH have Loan/Credit}

According to the survey, it was evident that among 200 respondents 178 (89\%) have loan/credit and 22 $\mathrm{HHs}(11 \%)$ didn't have but some them have savings. Some people do not take loan but they have savings within the NGO. It didn't mean that respondent have lot of loan/credit. Respondents were engaged with local NGO that's why they have loan/credit. During survey it was found that average loan size per HHs is about BDT 31,814 .

Table 3. Loan/Credit information of the respondents

\begin{tabular}{|llll|}
\hline SL No. & Response & Number of $\mathbf{H H}$ & $\%$ \\
\hline 1 & Yes & 178 & 76.0 \\
2 & No & 22 & 24.0 \\
& Total & $\mathbf{2 0 0}$ & \\
\hline
\end{tabular}

\section{Whether Respondent HHs have Savings}

According to the survey, it was evident that among 200 respondents $98.5 \% \mathrm{HHs}$ have savings. It does not mean that respondent have lot of savings. All the respondents were engaged with local NGO that's why they have savings.

\section{Respondent HHs has Bank Account}

According to the survey it was evident that among 200 respondents $129 \mathrm{HHs}(64.5 \%)$ didn't have any bank account. But respondents were engaged with local NGO's and many of them have DPS within the NGO's also. Only $35.5 \%$ respondent HHs has bank account in the formal bank.

\section{Respondent HHs takes loan from Money Lender}

According to the survey it was evident that only $1 \%(2 \mathrm{HHs})$ of the respondents takes loan from local money lender. It means respondent have enough access to local NGO's for credit facilities. 


\section{Cuchia Related Information}

\section{Cuchia Culture Practices}

During survey, several questions have been asked to the respondents. As we know people in those areas didn't culture cuchia though cuchia is very familiar to them. After harvesting fish, a big number of people caught cuchia from open field what they called beel, paddy field and other open water bodies and they sold it to the local bapari paikar or arotdar. Some of them also take cuchia as meal because cuchia known to them is very delicious \& nutritious food as well as medical values also.

Table 4. Cuchia culture practice

\begin{tabular}{|c|c|c|c|c|c|c|}
\hline \multirow[b]{2}{*}{$\begin{array}{l}\text { Kind of } \\
\text { aquaculture/cuchia } \\
\text { culture practice }\end{array}$} & \multicolumn{6}{|c|}{ Response $(n=200)$} \\
\hline & $\begin{array}{l}\text { Not } \\
\text { Applicable } \\
(=0)\end{array}$ & $\begin{array}{l}\text { Strongly } \\
\text { disgree }(=1)\end{array}$ & $\begin{array}{l}\text { Disagree } \\
(=2)\end{array}$ & $\begin{array}{l}\text { Moderately } \\
\text { Agree }(=3)\end{array}$ & $\begin{array}{l}\text { Agree } \\
(=4)\end{array}$ & $\begin{array}{l}\text { Strongly } \\
\text { agree }(=5)\end{array}$ \\
\hline Easy to learn & $\begin{array}{l}09 \\
(5)\end{array}$ & $\begin{array}{l}12 \\
(6)\end{array}$ & $\begin{array}{l}31 \\
(15)\end{array}$ & $\begin{array}{l}63 \\
32\end{array}$ & $\begin{array}{l}36 \\
(18)\end{array}$ & $\begin{array}{l}49 \\
(25)\end{array}$ \\
\hline Risky & $\begin{array}{l}8 \\
(4)\end{array}$ & $\begin{array}{l}13 \\
(7) \\
\end{array}$ & $\begin{array}{l}35 \\
(18)\end{array}$ & $\begin{array}{l}72 \\
(35) \\
\end{array}$ & $\begin{array}{l}46 \\
(23)\end{array}$ & $\begin{array}{l}26 \\
(13)\end{array}$ \\
\hline $\begin{array}{l}\text { Complementary to the } \\
\text { other agriculture } \\
\text { practice }\end{array}$ & $\begin{array}{l}0 \\
0\end{array}$ & $\begin{array}{l}0 \\
0\end{array}$ & $\begin{array}{l}25 \\
(14)\end{array}$ & $\begin{array}{l}55 \\
(28)\end{array}$ & $\begin{array}{l}36 \\
(18)\end{array}$ & $\begin{array}{l}84 \\
(42)\end{array}$ \\
\hline $\begin{array}{l}\text { Requires a lot of } \\
\text { investment }\end{array}$ & $\begin{array}{l}0 \\
0\end{array}$ & $\begin{array}{l}6 \\
(3)\end{array}$ & $\begin{array}{l}19 \\
(10)\end{array}$ & $\begin{array}{l}69 \\
(35)\end{array}$ & $\begin{array}{l}82 \\
(41)\end{array}$ & $\begin{array}{l}24 \\
(12)\end{array}$ \\
\hline $\begin{array}{l}\text { Produces enough fish } \\
\text { for HH's needs }\end{array}$ & $\begin{array}{l}0 \\
(0)\end{array}$ & $\begin{array}{l}7 \\
(3)\end{array}$ & $\begin{array}{l}15 \\
(8)\end{array}$ & $\begin{array}{l}88 \\
(44)\end{array}$ & $\begin{array}{l}65 \\
(33)\end{array}$ & $\begin{array}{l}25 \\
(12)\end{array}$ \\
\hline $\begin{array}{l}\text { Improved HH's standard } \\
\text { of living }\end{array}$ & $\begin{array}{l}3 \\
(2)\end{array}$ & $\begin{array}{l}46 \\
(23)\end{array}$ & $\begin{array}{l}47 \\
(24)\end{array}$ & $\begin{array}{l}80 \\
(40)\end{array}$ & $\begin{array}{l}6 \\
(3)\end{array}$ & $\begin{array}{l}18 \\
(9)\end{array}$ \\
\hline
\end{tabular}

\section{Whether Cuchia Culture is Easy to Learn}

Among the selected respondents people were asked during survey whether cuchia culture is easy to learn. $\mathrm{HHs}$ response is illustrated in the above figure. It was revealed that almost $25 \%$ strongly agree and $17 \%$ agree that cuchia culture is easy to learn. Among the respondent only $5 \% \mathrm{HHs}$ told that cuchia culture is not easy.

\section{Whether Cuchia culture is Risky}

Among the selected respondents people were asked during survey whether cuchia culture is risky. $\mathrm{HHs}$ response is illustrated in the above figure. It was revealed that almost $99 \%$ strongly agree and only $1 \%$ agree that cuchia culture risky. 


\section{Whether Cuchia Culture is Complementary to the Other Agriculture Practice}

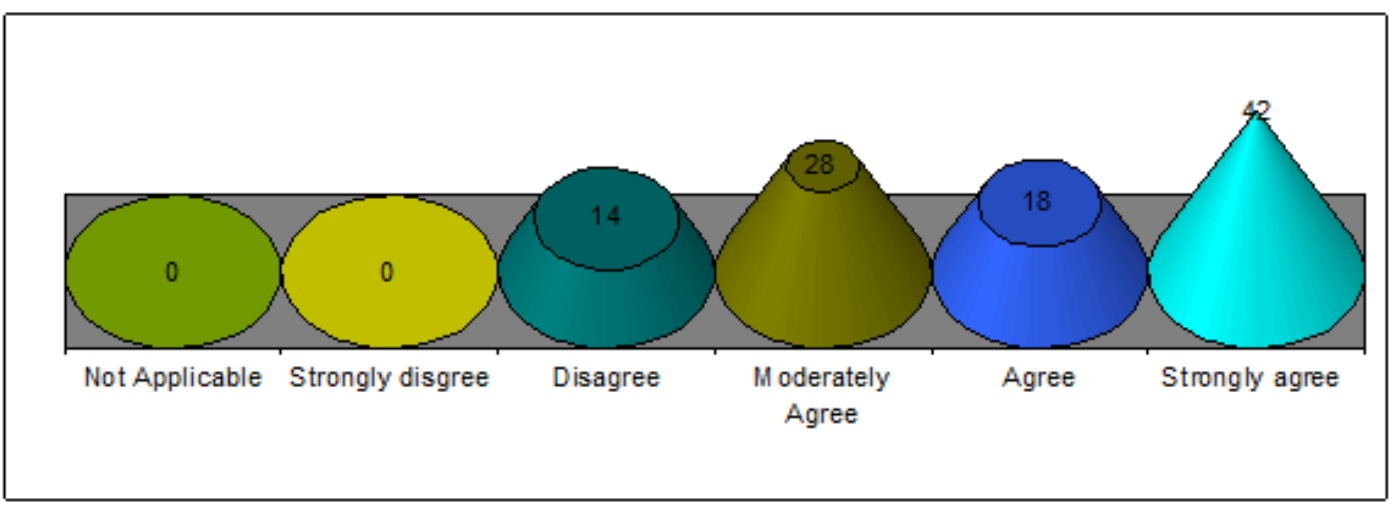

Figure 5. Cuchia culture is Complementary to the other agriculture practice

Survey result indicates that $42 \% \mathrm{HHs}$ strongly agreed that cuchia culture complement other agriculture practice. Among the respondents $14 \%$ disagree that cuchia culture is not complement other agriculture practices.

\section{Whether Cuchia Culture Requires Lot of Investment}

Among the selected respondents people were asked during survey whether cuchia culture required lot of money. $\mathrm{HH}$ s response is illustrated in the above figure. It was revealed that almost $12 \%$ respondents strongly agreed, $41 \%$ respondents agreed and 35\% moderately agreed that cuchia culture required lot of money. Actually there are different model for cuchia culture of which constructed house required more money than other model like hapa, ditch etc.

\section{Whether Cuchia Culture Produces Enough Fish for Household's Needs}

Among the selected respondents people were asked during survey whether cuchia culture produced enough fish for $\mathrm{HHs}$ use. HHs response is illustrated in the above figure. It was revealed that almost $13 \%$ strongly agreed that cuchia culture produced enough fish for $\mathrm{HHs}$ use. About $4 \%$ respondents have no idea that cuchia can be taken as meal. As we know Bangladesh may earn lot of foreign exchange through exporting cuchia. People may often use it as food but not regularly that's why it significant number of people disagree.

\section{Improvement of HH's standard of living}

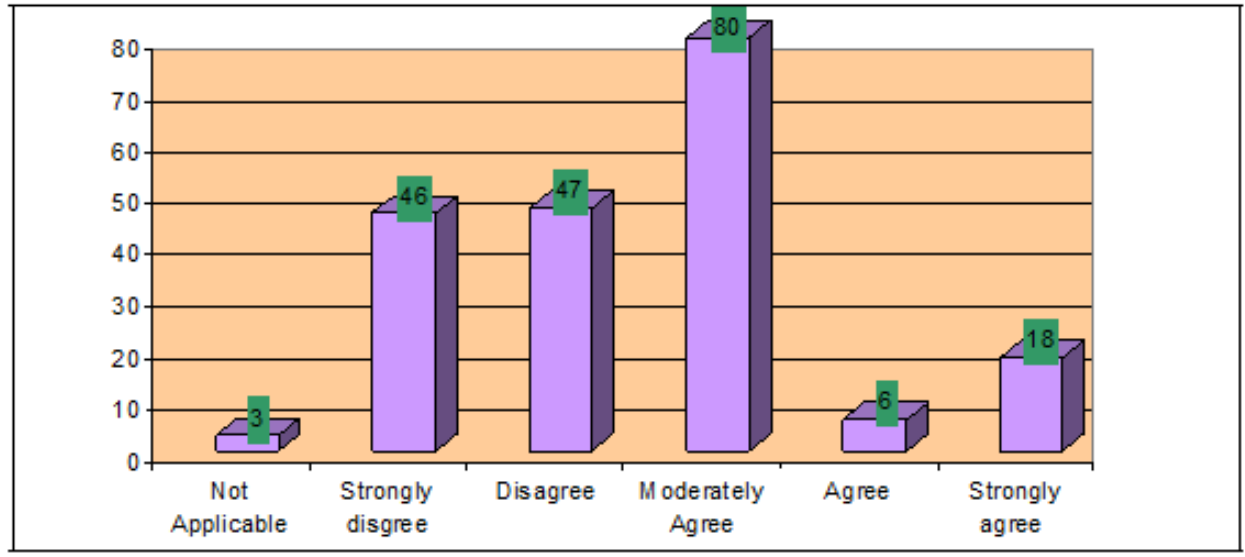

Figure 6. Improvement of HH's standard of living 
Among the selected respondents people were asked during survey whether cuchia culture improves HH's standard of living. HHs response is illustrated in the above figure. It was revealed that almost $46 \%$ respondents strongly disagreed, $47 \%$ disagreed that cuchia culture improves HH's standard of living. Actually, cuchia culture can be the partial IGA for the members that create $\mathrm{HHs}$ additional income (Figure 6).

\section{Cuchia Culture, Availability, Marketing in the Working Area}

\section{Whether Cuchia is a Fish}

It has been revealed that irrespective of categories $100 \%$ of the respondents mentioned that cuchia is a fish. It has been envisaged that people in surveyed upazilas know what cuchia is. So, the initiative didn't face any trouble to introduce cuchia in the working area which is a positive sign for starting this initiative.

\section{Where Cuchia Available}

All the respondents noticed that cuchia is available in beel and pond. People who already practice cuchia in ditch they mentioned that cuchia is available in ditch also.

Table 5. Cuchia available

\begin{tabular}{|llll|}
\hline SL No. & Response & Number of respondents & $\%$ \\
\hline 1 & Beel and Pond & 197 & 98.5 \\
2 & Pond & 3 & 1.50 \\
& Total & 200 & \\
\hline
\end{tabular}

\section{Harvest Area of Cuchia}

Here respondents gave multiple answers. Almost 54\% respondent noticed that they harvest cuchia from Beel and Pond but $46 \%$ strongly notices that they harvest cuchia from beel only. They also mentioned that abundance of cuchia found in beel rather than pond and other areas (Figure -7).

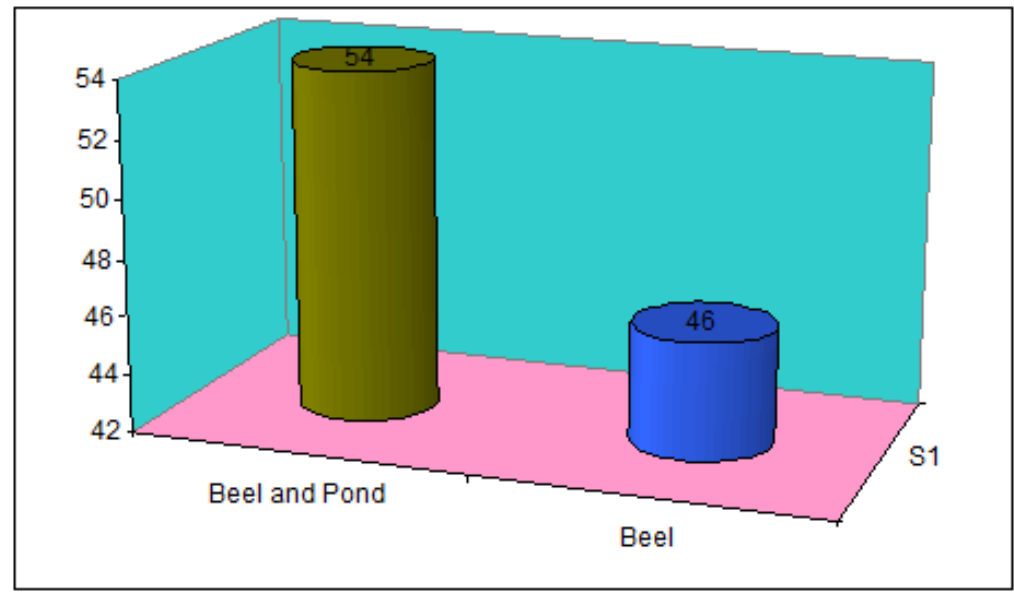

Figure 7. Harvest area of Cuchia

\section{Frequency of Cuchia Taking as Meal Weekly}

Based on survey result it was evident that $74 \%$ respondent took cuchia as meal. In the served area $84 \%$ respondents are fond of cuchia of which $58 \%$ are Hindu and $16 \%$ are Monipuri ethnic people whom take cuchia as their regular meal based on its availability in the survey area. 


\section{Whether Respondents Have Involved in Selling/Trading Cuchia}

It has been revealed that irrespective of categories $52 \%$ of the respondents are involved in cuchia selling or trading. In Kamalgonj upazila, cuchia is a seasonal business so people involved seasonally in this business.

\section{Whether Cuchia Culture is Profitable Business}

Among the selected respondents people were asked during survey whether cuchia is a profitable business. Almost $96.5 \%$ respondent mentioned that cuchia culture is a profitable business. In the surveyed area, people are not culture cuchia now. They caught cuchia from natural source like paddy field, wetland, beel, creek and pond.

Table 6. Cuchia culture is profitable business

\begin{tabular}{|llll|}
\hline SL No. & Response & Number of respondents & $\%$ \\
\hline 1 & Yes & 193 & 96.5 \\
2 & No & 5 & 2.5 \\
3 & No ldea & 2 & 1.0 \\
& Total & $\mathbf{2 0 0}$ & $\mathbf{1 0 0 . 0}$ \\
\hline
\end{tabular}

\section{Whether Respondent Know Basic Information of Pond/Hapa/Others for Cuchia Farming}

Among the selected respondents people were asked about the basic information of cuchia farming. Almost $100 \%$ respondent mentioned that they don't culture cuchia in ditch, hapa, pond or others way. They also mention that they don't have technical idea for cuchia farming. But they can harvest cuchia from open water body where cuchia naturally grown.

\section{Whether Respondent Know Basic Information of Cistern for Cuchia Farming}

Among the selected respondents people were asked about the basic information of cistern for cuchia farming. Almost $100 \%$ respondent mentioned that they don't know the culture technique of cuchia in cistern. They also mention that they don't have technical idea for cuchia farming in a cistern. But they also mention that the dipo owners are stock cuchia in cistern for buying and selling purpose.

\section{Whether Respondent Know Basic Information of Ditch for Cuchia Farming}

Among the selected respondents people were asked about the basic information of ditch for cuchia farming. Almost 93\% respondent mentioned that they don't know the culture technique of cuchia in a ditch. Most of them also revealed that they first time listen this sort of ideas for cuchia farming.

\section{Months/Periods Adequate Cuchia is Available}

Among the selected respondents people were asked during which month's adequate cuchia is available. It was revealed that almost $100 \%$ respondents told that huge number of cuchia found 3 months in a year in the working area of which $74 \%$ told thast during the month bangla Pous, magh and falgun cuchia is available and $26 \%$ told that in the month of Agrahaon and magh cuchia is available in the working area.

\section{Months/Periods Cuchia don't Found or Less Found}

Among the selected respondents people were asked during which month's less amount of cuchia is available. HHs response is illustrated in the above figure 16. It was revealed that almost $43 \%$ respondents told that less amount of cuchia found during bangla month Chaitra, only $19 \%$ told in the month of falgun-chaitra \& rest of the $38 \%$ told cuchia less found 6 months in a year like Joistha, Ashar, Sharabon, Vadra, Ashmin, Kartik (Figure 8). 


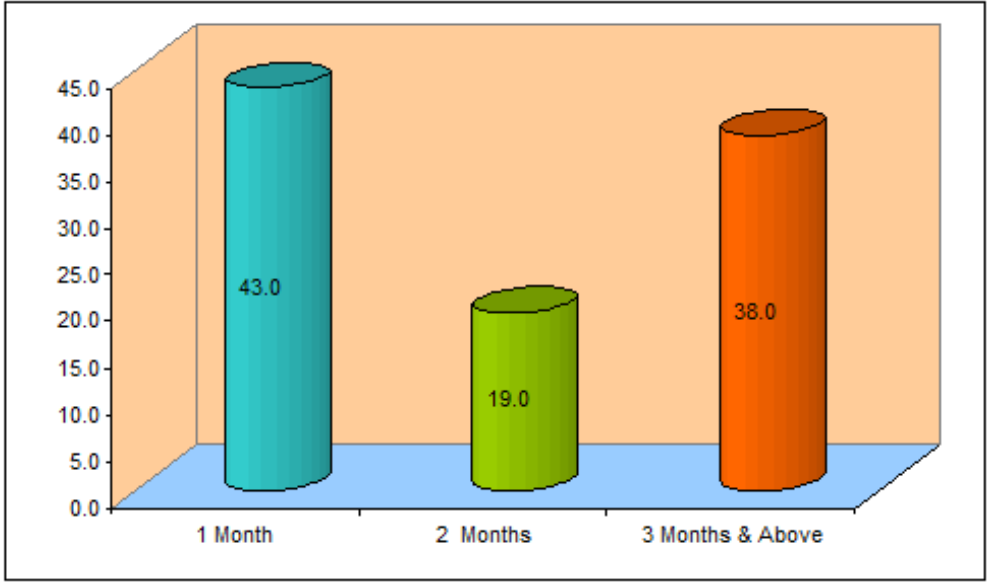

Figure 8. Months/periods cuchia don't found or less found

\section{Number of Months Most Difficult to Get Cuchia}

Among the selected respondents people were asked during which month's most difficult to get cuchia. $\mathrm{HH}$ response is illustrated in the below table.

Table 7. Number of months most difficult to get cuchia

\begin{tabular}{|llll|}
\hline SL No. & Response & Number of respondents & $\%$ \\
\hline 1 & Boishakh-Chaitra & 1 & 0.50 \\
2 & Boishakh-kartik & 199 & 99.50 \\
& Total & $\mathbf{2 0 0}$ & $\mathbf{1 0 0 . 0}$ \\
\hline
\end{tabular}

\section{Price of cuchia}

Below figure- 9 showed that only of $35.5 \%$ respondents told the average price range per $\mathrm{kg}$ cuchia in the working area is upto BDT 200. A total of $63 \%$ respondents mentioned that average price range per $\mathrm{kg}$ cuchia in the working area is BDT 201-500. About $1.5 \%$ respondents don't have any idea about the price of cuchia.

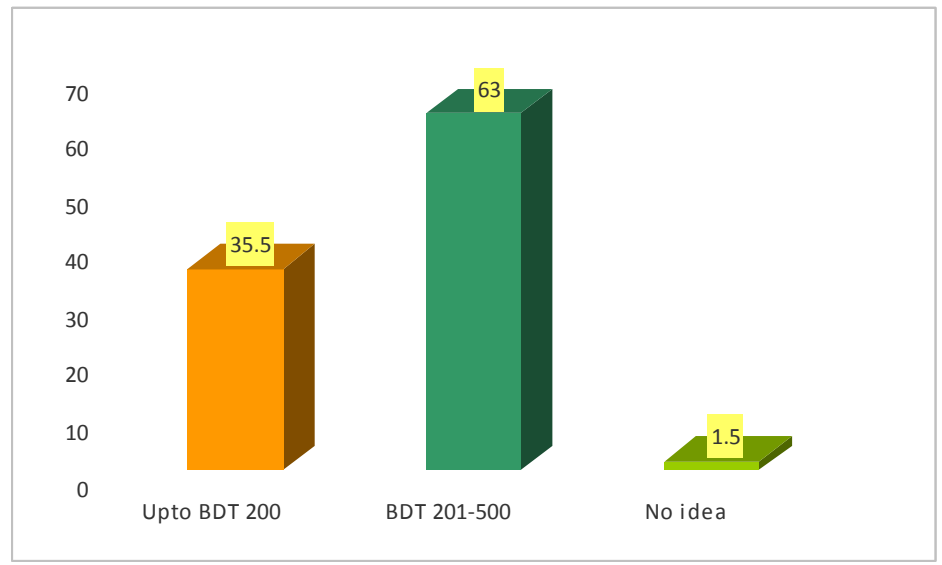

Figure 9. Price of Cuchia per kg

\section{Whether respondent grading cuchia before sell}

About $99.50 \%$ respondents don't grading their cuchia before sell. They also told that cuchia above $70 \mathrm{gm}$ are not eligible for export market. They also mention that cuchia above $500 \mathrm{gm}$ has upper market price. 


\section{Time of Highest Price for Cuchia Selling}

It was revealed that almost $100 \%$ respondents mentioned that during the period of october to december they get the highest market price of cuchia in the working area.

\section{Whether Respondents Get Support from Different Sources for Cuchia Farming}

It was revealed that almost $100 \%$ respondents mention that they don't get support for cuchia farming neither govt. nor NGO sector. But few of the respondents told that recently a local NGO named 'Heed bangladesh' has taken an initiative to support for the cuchia farmers as well as cuchia traders in the surveyed upazilla.

\section{Whether Respondent Engage in Cuchia Breeding for Getting Cuchia}

HHs response is illustrated in the below table-8. It was revealed that almost $100 \%$ respondents mention that they are not involved in cuchia breeding. Another point to be not ed that, they don't know the technical aspects of cuchia breeding. They only engage themselves in harvesting cuchia from natural sources.

Table 8. Respondents engage in cuchia breeding

\begin{tabular}{|cccc|}
\hline SL No. & Response & Number of respondents & $\%$ \\
\hline 1 & Yes & 0 & 0.0 \\
2 & No & 200 & 100.0 \\
& Total & 200 & \\
\hline
\end{tabular}

\section{CONCLUSION}

Monopterus cuchia or mud eel is a delicious, nutritious, indigenous freshwater fish of Bangladesh. It's an export fishery product that is playing an important role in international markets. It can generate employment directly and indirectly for more people in the marketing and other associated business in the working area. This baseline report will help to prevent it from being extinct and can bring a new high priced fish into aquaculture for supporting export earnings. This mud eel is a delicate and potential resource for consumption and livelihood maintenance of tribal communities of Bangladesh, which has declined during the last three to four decades.

\section{RECOMMENDATIONS}

- Creating awareness in the working area to culture cuchia rather than over harvesting of cuchia from natural sources especially in the ethnic community.

- Government and aspiring NGOs along with mass-media should take functional steps in order to disseminate the knowledge on cuchia farming across the country.

- Developing culture technique of cuchia and provide effective training on cuchia farming to the members.

- Bangladesh Fisheries Research Institute (BFRI) needs to take functional role to develop a costeffective culture technique for cuchia.

- Developing a strong market linkage among the cuchia harvesters, faria, paikar, arotdars, the depo owners and the exporters in order to ensure fair price of cuchia.

- Special loan policies need to be design for the cuchia harvesters or enthusiastic cuchia farmers as though they have the easy access of getting loan facility.

- Natural ground is the only one source for getting cuchia not only in the working area but also the whole country. Artificial propagation, development of nursing and culture technologies is important for the conservation of this commercially important species.

- Financial institutions like Govt. and non-govt. banks should introduce flexible loan facilities for the cuchia farmers and exporters owing to flourish the business.

- Government sectors specially Department of Fisheries (DoF) and Palli karma-Sahayak Foundation (PKSF) need to take special projects to promote cuchia farming.

- Encouraging ethnic community to come forward on cuchia farming in the working area. 


\section{REFERENCES}

1. Chakraborty BK and Nur NN, 2009. Study on aquatic biodiversity of Medha Beel in the Northern Bangladesh. Journal of Crop and Weed, India, 5(2): 4-11.

2. Das RD, Sharmin S \& Rahman M, 2016. Controlled breeding and nursery technique of freshwater kuchia. Jatio matshaw saptaho sankolon 2016 (in Bengali). Department of Fisheries, Ministry of Fisheries and livestock, Dhaka, Bangladesh. pp. 76-78.

3. Disaster E 1990: Floodplain protection in Central Europe. World Wildlife Found (WWF) Institute of Floodplains Ecology Visiting Card 31/90, Germany.

4. Doha S and Hye MA 1970. Fecundity of Padma River hilsa, Hilsa ilisha (Ham.). Pakistan Journal of Science, 22 (3 \& 4): 176-178.

5. IUCN, 2000. List of threatened animal of Bangladesh. Paper presented in the Workshop on Bangladesh Red Book of Threatened Animals. 22 Feb. 1998. Dhaka.13 p.

6. Jahan DA, Rashid J, Khan MM \& Mahmud Y, 2014. Reproductive biology and gonad histology of mud eel, Monopterus cuchia (Hamilton, 1922). International Journal Life Sciences Biotechnology and Pharma Research, 3(1): 231-238.

7. Jana D. \& Dasgupta M, 2008. Length-weight relationship and relative condition of the mud eel. Monopterus cuchia (Hamilton, Buchanan) from West Bengal. J. Inland Fish. Soc. Ind. 40(1): 54-58.

8. Jhingran AG, 1972. Fluctuation in the ponderal index of the gangetic ancovy Satipinna phasa (Ham.) and interpretation of "Salmonid bands" and spawning marks. Proceeding of the Indian Natural Science Academy, 37 (4): 1-62.

9. Lagler KF, 1956. Freshwater Fishery Biology 2nd ed., W. M. C. Brown Company, Bubuque, Lowa, UK. $541 \mathrm{pp}$.

10. Munshi JSD, Roy PK \& Nasar SST, 1989. Oxygen uptake capacity of larval respiratory organs of airbreeding swamp mud eel, Monopterus cuchia (Ham.): A morphometric study. Proc. Indian National Science Academy, B55, Nos. 5 \& 6, pp. 309-316.

11. Narejo NT, Rahmatullah SM and Rashid MM, 2002. Length-weight relationship and relative condition factor (Kn) of Manopterus cuchia (Hamilton). Indian Journal of Fisheries, 49(3): 329-333.

12. Narejo NT, Rahmatullah SM \& Rashid MM, 2003. Reproductive biology of air-breathing freshwater mud eel, Monopterus cuchia (Ham) from Bangladesh. Indian Journal of Fisheries, 50(3): 395-399.

13. Nasar SST, 1989. Parental care and fecundity in Monopterus cuchia (Ham). Journal of Fish Biology, $1(1): 67-70$.

14. Rahman AKA, 1989. Fresh water Fishes in Bangladesh, pp.263-264.

15. Rashid H, Alam J, Mithu M \& Hossain MAR, 2012. Study of reproductive physiology of mud eel, Monopterus cuchia for artificial propagation. $5^{\text {th }}$ Fisheries Conference and Research Fair. P. 1.

16. Singh BN, Towheed MA and Munshi JSD, 1989. Respiratory adaptations in the larvae of Monopterus cuchia (Ham.). Journal of Fish Biology, 34: 637- 638.

17. Talwar PK and Jhingran VG, 1991. Inland Fishes of India and Adjacent Countries. Oxford \&IBH Publishing Co. Pvt. Ltd. India. 1\&2: 1158 pp.

18. Zahan AD, Das RD, Rahman M and Sharmin S, 2016. Breeding and fry production techniques of Monopterus cuchia. BFRI invented technologies and research success 2009-2016 (in Bengali). Bangladesh Fisheries Research Institute, Ministry of Fisheries and livestock, Dhaka, Bangladesh. pp. 4-6. 